\title{
PENERAPAN JURNALISME PRESISI PADA PEMILIHAN UMUM KEPALA DAERAH (PILKADA) DI INDONESIA
}

\author{
Rahmawati Latief \\ Fakultas Dakwah dan Komunikasi \\ Universitas Islam Negeri (UIN) Alauddin Makassar \\ Email : rahma.latief@gmail.com
}

\begin{abstract}
Abstrak
Jurnalisme presisi diketahui sebagai genre jurnalisme yang menautkan antara pekerjaan jurnalistik dengan pekerjaan saintis sosial. Jurnalisme presisi adalah metode peliputan berita dengan menggunakan riset ilmu sosial di mana peristiwa, karakteristik, tingkah laku atau sikap diubah menjadi angka-angka untuk ditelaah dan dianalisis dengan metode survei, analisa isi dan eksperimen lapangan. Kemunculan jurnalisme ini disebabkan karena beberapa fenomena ekonomi sosial budaya politik yang tidak lagi mampu dijelaskan melalui peliputan berita konvensional yang sifatnya naratif dan deskriptif khususnya isu-isu kontestasi Pemilihan Umum (Pemilu). Jurnalisme presisi ini menjawab ekspektasi masyarakat untuk menikmati laporan pemberitaan yang objektif, kredibel dan komprehensif. Dukungan metode penelitian sosial yang rasional dan akurat menjadi perekat jurnalisme presisi sebagai barometer bagi masyarakat dalam menentukan pilihan politiknya sekaligus preferensi bagi semua elemen masyarakat untuk memprediksi pemenang kontestasi Pemilihan Umum Kepala Daerah (Pilkada) di Indonesia.
\end{abstract}

Kata Kunci : analisa isi, jurnalisme, pilkada, presisi, survei

\section{PENDAHULUAN}

Dinamika Pemilihan Umum Kepala Daerah atau PILKADA serentak 2018 di Indonesia menelurkan ragam kejutan peristiwa. Salah satunya fenomena jurnalisme presisi yang semakin diminati para pengelola media massa. Genre jurnalisme ini memberikan informasi riset dengan metode ilmiah yang kredibel kepada masyarakat untuk menentukan pilihan-pilihan politiknya. Praktik jurnalisme ini juga menjadi salah satu referensi utama para calon kepala daerah untuk menakar elektabilitasnya. Elektabilitas yang tinggi merupakan salah satu indikator yang mengkonstruksi kepercayaan diri para calon eksekutif untuk berkompetisi di daerah pemilihan masing-masing.

Setiap tahunnya perkembangan jurnalisme presisi ini semakin meningkat dan selalu beririsan dengan pesta demokrasi rakyat. Pemilihan Umum Kepala Daerah (PILKADA), Pemilihan Umum Presiden dan Wakil Presiden (PILPRES) dan Pemilihan Umum Anggota Dewan Perwakilan Rakyat, Dewan Perwakilan Daerah, dan Dewan Perwakilan Rakyat Daerah (Pemilu Legislatif atau PILEG) selalu duduk berdampingan dengan jurnalisme presisi. Mengapa 
demikian? karena isu pemilihan umum adalah manifestasi ekspresi pendapat umum (public opinion) yang tertinggi karena secara asasi pemilihan umum sangat menghargai pendapat pribadi yang memiliki arti politik sangat signifikan. Kedua, angka-angka yang dihadirkan dalam jurnalisme presisi bukanlah sekadar angka matematis melainkan dipandang sebagai representasi dari pendapat masyarakat yang memiliki pengaruh terhadap kemenangan calon pemimpin. Ketiga, kehadiran jurnalisme presisi melegitimasi tentang pentingnya laporan jurnalistik yang berbasis metode ilmiah sebagai parameter masyarakat untuk mempersepsi fenomena politik sehingga mampu berdemokrasi secara elegan dan kompetitif.

Pilkada serentak 2018 menorehkan catatan semakin menguatnya dinamika jurnalisme presisi di Indonesia. Media massa seperti Kompas, Tempo, Metro TV, TV One, Trans TV, Republika dan Media Indonesia saling berkompetisi menyajikan peliputan berita jurnalisme berbasis data dengan ekspektasi laporan yang disajikan lebih kredibel, terpercaya, representatif dan komprehensif. Meski harus diakui, dinamika jurnalisme presisi di Indonesia harus lebih banyak berbenah dibandingkan dengan media massa di negara-negara maju seperti majalah Fortune di Amerika Serikat yang telah memulai jurnalisme presisi sejak tahun 1935 dan merupakan media massa yang kali pertama merintis penerapan jurnalisme presisi dalam praktik jurnalistik.

Dengan demikian, artikel ilmiah ini bertujuan untuk mengurai lebih dalam penerapan jurnalisme presisi pada Pemilihan Umum Kepala Daerah serentak 2018 di Indonesia dengan ekspektasi pembaca mampu memahami signifikansi keterkaitan jurnalisme presisi dengan isu pemilihan umum.

\section{SELAYANG PANDANG JURNALISME PRESISI}

Secara etimologis, jurnalisme presisi berasal dari kata bahasa Inggris yaitu Precision Journalism adalah jurnalisme yang menghendaki ketepatan bukan jurnalisme tebak-tebakan. Sedangkan pengertian jurnalisme presisi secara terminologi yang dikemukakan oleh Philip Meyer adalah aplikasi metode ilmiah sosial dan perilaku ke dalam praktik kerja jurnalistik. ${ }^{1}$ Pengertian ini lebih jauh diuraikan bahwa jurnalisme presisi adalah metode peliputan berita dengan menggunakan riset ilmu sosial di mana peristiwa, karakteristik, tingkah laku atau sikap

\footnotetext{
${ }^{1}$ Philip Meyer. The New Precision Journalism. (Bloomington, Indiana: Indiana University Press, 1991) hal. 2-3
} 
diubah menjadi angka-angka untuk ditelaah dan dianalisis dengan metode survei, analisa isi dan eksperimen lapangan.

Meyer pun menekankan penggunaan metode-metode kuantitatif dalam desain risetnya, yakni penggunaan angka-angka sebagai alat ukur dan evaluasi. Metode kuantitatif digunakan untuk mengukur opini khalayak melalui survei, hal ini terkait dengan upaya simplikasi pengukuran aspek sosial kemasyarakatan agar tidak bertele-tele dan rumit. Laporan berita akan menonjolkan angka-angka statistik sosial yang lebih mudah dipahami. Berbagai dimensi peristiwa kemanusiaan pun akan terkalkulasi ke dalam hitungan kuantitatif sosial. ${ }^{2}$ Para reporter tidak diharapkan menjadi ahli-ahli di bidang desain riset ataupun prosedural pelaksanaan survei, tetapi memiliki pengetahuan tentang langkah-langkah kerja riset ini akan sangat membantu dalam proses peliputan. Metode yang paling banyak digunakan dalam jurnalisme presisi adalah riset survei, atau lebih dikenal sebagai polling opini publik.

Istilah atau genre jurnalisme presisi kali pertama diperkenalkan Profesor Emeritus Philip Meyer yang telah mengubah praktik jurnalisme di dunia. Philip Meyer berusia 87 tahun, Mantan jurnalis Amerika dengan segudang pengalaman selama 26 tahun di dapur redaksi sebagai reporter, editor dan koresponden. Karir professional jurnalistiknya dimulai saat dia magang di surat kabar lokal Topeka Daily Capital, kemudian pindah ke surat kabar Miami Herald di Florida sebagai reporter, dan berprofesi koresponden Washington D.C untuk Akron Beacon Journal, terakhir 1978-1981. Setelah itu dia memilih pensiun dari profesi jurnalis dan akhirnya berpindah profesi sebagai akademisi di University of North Carolina di Chapel Hill hingga sekarang.

Selama kariernya sebagai reporter dan koresponden, Meyer menghabiskan waktunya belajar ilmu politik pada jenjang pendidikan magister di University of North Carolina yang membuatnya sangat tertarik dengan metode penelitian ilmu sosial dan perilaku. Setelah itu dalam kurun waktu 1966-1967, dia terpilih sebagai Nieman Fellow di Harvard University, di mana ia lebih mendalami metode penelitian kuantitatif ilmu sosial. Metode inilah yang digunakan pada peliputan laporan kerusuhan Detroit pada tahun 1967 saat dia ditugaskan untuk mendesain peliputan tersebut oleh Detroit Free Press. Philip Meyer mengusulkan penelitian ilmiah untuk mengidentifikasi penyebab tuntutan atau gugatan perusuh. Proyek ini menggunakan hipotesis dan penggunaan komputer untuk menguji sampel secara statistik. Proyek peliputan ini

${ }^{2}$ Septiawan Santana K. Jurnalisme Investigasi. (Jakarta: Yayasan Obor Indonesia, 2003) hal. 199 
memenangkan penghargaan jurnalistik yang paling penting dan bergengsi yaitu Pulitzer Prize untuk kategori General Local Reporting pada tahun $1968 .^{3}$

Pengalaman di dalam dan di luar dapur redaksi menjadikan Meyer sebagai salah satu jurnalis yang memiliki kontribusi terbesar dalam bidang jurnalisme presisi dan beliau semakin dikenal di berbagai negara ketika kali pertama menerbitkan buku Precision Journalism pada 1973 yang dianggap sebagai cikal bakal peletak dasar-dasar jurnalisme presisi. Buku ini membahas mengenai jurnalisme yang lebih dekat dengan tradisi sains yang menggunakan metode penelitian ilmu sosial dan perilaku dalam praktik jurnalistik.

Kini Philip Meyer telah menjadi profesor emeritus di School of Journalism and Mass Communication di University of North Carolina di Chapel Hill, USA. Dia telah melakukan banyak penelitian di bidang kualitas jurnalisme, jurnalisme presisi, jurnalisme kewarganegaraan (civic journalism), polling atau jajak pendapat, industri surat kabar, dan teknologi komunikasi.

Jenis jurnalisme ini sering juga disebut sebagai new journalism (jurnalisme baru), computer-assisted journalism (jurnalisme yang dibantu komputer), scientific journalism (jurnalisme ilmiah), quatitative journalism (jurnalisme kuantitatif) dan database journalism (jurnalisme berbasis data). Melihat sejarah kemunculan jurnalisme presisi di Amerika terlihat bahwa teknik jurnalisme ini muncul karena jurnalis ingin lebih teliti dalam mengungkapkan suatu peristiwa. Secara praktik jurnalisme presisi sebenarnya telah hadir di ranah jurnalisme Amerika sejak 1935, tepatnya saat majalah Fortune mengeluarkan hasil penemuan polling terkait jenis rokok yang dikonsumsi masyarakat Amerika.

Stephen K Doig, mantan jurnalis Amerika Serikat dan seorang profesor Jurnalistik di Arizona State University juga menyebutkan bahwa kemungkinan besar penggagas awal untuk jurnalisme presisi terjadi pada malam pemilihan presiden AS tahun 1952. Liputan ini dilakukan oleh Walter Cronkite, seorang jurnalis politik dan juga koresponden Washington DC di CBS News atau Colombia Broadcasting System dengan menggunakan analisis komputer UNIVAC 1 tentang hasil awal yang memprediksi secara benar bahwa Dwight Eisenhower akan dengan mudah memenangkan kursi kepresidenan Amerika Serikat sebagai presiden ke-34. ${ }^{4}$

\footnotetext{
${ }^{3}$ Marília Gehrke and Luciana Mielniczuk. "Philip Meyer, the outsider who created Precision Journalism". Intexto Volume 39, 2017. DOI: http://dx.doi.org/10.19132/1807-8583201739. Hal 4-13.

4 Stephen K. Doig. "Precision Journalism". The International Encyclopedia of Communication,First Edition.Edited by Wolfgang Donsbach. 2012 (USA : John Wiley \& Sons,Ltd) hal. 1 DOI:10.1002/9781405186407.wbiecp096.pub2
} 
Jurnalisme presisi, seperti peliputan konvensional, adalah sebuah metode penyelidikan atau pencarian kebenaran. Perbedaannya dengan metode penyelidikan lain adalah penggunaan metode penelitian kuantitatif ilmu sosial dalam pencarian informasi untuk membuat berita. Ada dua alasan utama penyebab kemunculan jurnalisme presisi. $^{5}$

Pertama, banyak peristiwa yang tidak dapat dijelaskan dengan metode liputan biasa : narasi ataupun deskripsi. Peristiwa itu amat rumit yang memerlukan kepastian seperti dalam peristiwa pemilihan umum. Ketika media massa meliput dan meramal hasil pemilu, tidak memungkinkan menerapkan metode wawancara konvensional. Jurnalis tidak bisa hanya mengandalkan pendapat beberapa pakar yang memprediksikan siapa yang memenangkan pemilu. Jurnalis juga tidak bisa membuat analisis prediksi pemilu berdasarkan pada pengamatan semata. Agar laporan pemberitaannya tepat, media harus melakukan penelitian yang cermat yang mengukur preferensi pemilih dan itu bisa dicapai dengan melakukan metode survei dan atau polling. Kedua, berkaitan dengan kebutuhan dan keinginan pembaca. Pembaca lebih menginginkan berita yang mendalam, informatif, objektif dan komprehensif. Dalam berita mengenai pemilu seperti liputan dan ramalan siapa yang menjadi calon presiden dan calon wakil presiden dan yang terpilih menjadi presiden dan wakil presiden adalah berita yang ditunggutunggu kehadirannya oleh masyarakat di Amerika. Kredibilitas suatu media di antaranya juga diukur dari seberapa teliti mereka melaporkan dan meramalkan kemenangan partai atau presiden dalam pemilihan umum.

Jurnalisme presisi sebenarnya bukanlah hal yang baru dalam kehidupan pers di Indonesia. Setidaknya hal ini telah diawali oleh harian Kompas yang telah mempraktikkannya sejak April 1971. Kala itu Kompas melalui bagian Penelitian dan Pengembangan (Litbang) yang berada di bawah naungan divisi redaksi melakukan penelitian pendapat umum atau polling bertemakan pemilihan umum. Hasil polling ini kemudian digunakan sepenuhnya untuk kepentingan mendukung pemberitaan. Selain Kompas, media massa yang lain seperti Media Indonesia, Republika dan Tempo juga menerapkan pekerjaan sejenis pada surat kabarnya masing-masing.

Pertanyaan yang kemudian muncul adalah kapan kira-kira jurnalisme presisi itu digunakan oleh jurnalis?. ${ }^{6}$ Pertama, jurnalis menghadapi suatu gejala sosial yang melibatkan

\footnotetext{
${ }^{5}$ Eriyanto. Metodologi Polling: Memberdayakan Suara Rakyat. (Bandung: PT. Remaja Rosdakarya, 1999), hal. 61

${ }^{6}$ Eriyanto. Metodologi Polling: Memberdayakan Suara Rakyat. (Bandung: PT. Remaja Rosdakarya, 1999), hal. 64-65
} 
banyak orang sebagai suatu fenomena sosial. Sebagaimana dikatakan Leo Bogard, antara jurnalistik dan metode ilmu sosial mempunyai wilayah yang sama yaitu mempelajari manusia dan fenomena sosial. Jurnalistik umumnya memakai wawancara atau pengamatan untuk mengungkapkan fenomena. Dengan metode ini, apabila berita yang ditulis adalah peristiwa personal tidak menjadi masalah, tetapi ketika fakta yang dihadapi adalah fenomena sosial, jurnalis akan mengalami kesulitan. Fenomena sosial amat kompleks dan menyertakan banyak sekali perbedaan pendapat. Jurnalis dapat menggunakan metode ilmu sosial untuk menjelaskan gejala sosial yang dihadapi. Dengan beragam metode teknik statistik, metode ilmu sosial mereduksi fenomena yang kompleks menjadi sederhana, melakukan generalisasi sehingga fenomena yang abstrak dapat dikenali. Perasaan publik, apa yang dipikirkan oleh masyarakat mampu diterjemahkan ke dalam kuantifikasi angka-angka.

Objek fenomena sosial ini seperti pada kasus hasil pemilihan walikota pada bulan Juni 2018 di Makassar yang dimenangkan oleh kotak kosong atau kolom kosong yang mana porsi pemberitaan media massa lokal maupun nasional terhadap kasus ini sangat viral, masif dan signifikan. Fenomena politik ini sangat menyejarah di Indonesia karena pasangan calon tunggal (Munafri Arifuddin-Andi Rachmatika Dewi (Appi-Cicu) yang didukung 10 partai politik pengusung dan memiliki dana sangat besar dan koneksitas yang tinggi dengan penguasa dan pengusaha akhirnya harus mengakui kekalahan kepada kotak kosong yang tidak memiliki calon, tidak mempunyai visi misi, tidak pernah berkampanye, bahkan tidak memiliki dana kampanye dan tidak memiliki dukungan partai politik pengusung. Kenapa hal ini terjadi? Mengapa mayoritas masyarakat di Makassar memilih kotak kosong? Apakah pilihan masyarakat terhadap kotak kosong berkorelasi dengan 'kezaliman' yang dilakukan oleh calon pasangan tunggal dengan calon incumbent atau petahana sebelumnya (Muhammad Ramdhan Pomanto)? Ataukah warga Makassar memiliki kecemasan jika pasangan Appi-Cicu yang memenangkan kontestasi maka pasangan ini akan mudah diintervensi oleh penguasa dan pengusaha? Dan sederet pertanyaan lain. Mau tidak mau, jurnalis harus melakukan penelitian, tidak cukup hanya melakukan liputan konvensional atau melakukan wawancara dengan pasangan calon tunggal ataupun petahana, pengamat politik, partai politik atau pihak KPUD dan BAWASLU, tetapi melakukan riset dengan metode sosial kuantitatif terhadap warga Makassar mengenai alasan atau movitasi utama mereka memenangkan kotak kosong dalam pemilihan walikota 2018. Sehingga 
jurnalis mampu mengambil kesimpulan secara lebih presisi dalam menjelaskan fenomena kemenangan kotak kosong.

Kedua, jurnalisme presisi digunakan ketika jurnalis menghadapi suatu gejala yang tidak tampak, yang kalau diungkap dapat menjelaskan banyak hal. Masalah yang dihadapi oleh jurnalis sebenarnya sama dengan persoalan yang dihadapi oleh peneliti sosial. Sebagaimana dikatakan Nafziger, editor dan wartawan tidak hanya bisa mengandalkan intuisinya untuk menulis objek yang ia amati terutama apabila hendak menjelaskan fenomena sosial. Jurnalis tidak dapat berhenti dengan melaporkan suatu kejadian atau peristiwa, tetapi perlu menarik makna dan arti dari peristiwa itu, terutama menjelaskan hubungan antara isu-isu publik yang muncul dengan sikap masyarakat terhadap isu yang berkembang. Reaksi tersebut tidak hanya perlu diamati tetapi juga diukur dengan melakukan penelitian.

Objek fenomena sosial ini seperti pada kekalahan pasangan Basuki Tjahaja Purnama (Ahok) dan Djarot Syaiful Hidayat (Djarot) pada kontestasi PILKADA DKI 2017. Fenomena politik menjadi liputan yang sangat viral di media massa nasional dan mancanegara. Elektabilitas atau tingkat keterpilihan pasangan Ahok-Djarot diberbagai lembaga survei nasional menunjukkan jauh lebih tinggi berbanding pasangan Anies Baswedan dan Sandiaga Uno, belum lagi tingkat kepuasan warga DKI Jakarta begitu tinggi terhadap kinerja pasangan incumbent atau petahana Ahok-Djarot, namun karena skandal isu SARA dan sentimen keagamaan atau yang dikenal dengan istilah politik identitas, akhirnya pasangan Ahok-Djarot gagal meraih kursi gubernur dan wakil gubernur DKI Jakarta.

Benar bahwa faktor isu SARA adalah penyebab kekalahan pasangan petahana, tetapi dibalik peristiwa itu khalayak media massa akan selalu bertanya: bagaimana mungkin kinerja petahana yang sangat apik begitu mudah dilupakan oleh warga DKI Jakarta? Dan umumnya beberapa kasus pilkada menunjukkan bahwa jika pasangan petahana memiliki penampilan kinerja yang bagus dan bermanfaat, maka kemungkinan besar akan terpilih kembali, namun hipotesa ini tidak berlaku bagi pasangan Ahok-Djarot. Apakah kekalahan Ahok-Djarot berhubungan dengan intervensi atau sentimen keagamaan partai pendukung oposisi terhadap warga DKI Jakarta? Ataukah penyebab kekalahan Ahok-Djarot disebabkan karena sebagian warga ingin memilih zona nyaman ketika pasangan Anies-Sandiaga memenangkan pertarungan maka dipastikan tidak akan terjadi pembelahan umat? Ataukah ada ketakutan dari pemilih warga muslim ketika yang menjadi pemimpin adalah pemimpin yang tidak seiman?. Dan sejumlah 
deretan pertanyaan lain, maka sesungguhnya jurnalis tidak lagi berhadapan dengan peristiwa, tetapi ia berhadapan dengan kecenderungan sosial, dan tentunya survei ilmiah adalah metode riset yang paling terpercaya untuk mengukur kecenderungan, sikap dan pendapat masyarakat.

\section{METODE DAN APLIKASI JURNALISME PRESISI}

Mengetahui apa yang harus dilakukan dengan data atau cara memperlakukan data adalah esensi dari jurnalisme presisi. Jurnalisme ini dianggap memiliki dua tahapan. Tahapan pertama adalah fase input, dimana data dikumpulkan dan dianalisis. Kemudian melangkah ke tahapan kedua yaitu fase output, dimana data dipersiapkan untuk diakses khalayak media massa. Menurut Philip Meyer, jurnalis hendaknya memperlakukan data dengan cara sebagai berikut : ${ }^{7}$

1. Mengumpulkannya dengan melakukan metode pengumpulan data.

2. Menyimpannya di dalam file-file komputer.

3. Mengambil kembali data-data yang dianggap penting dan menyortirnya.

4. Menganalisa data-data yang akan digunakan untuk kepentingan laporan pemberitaan.

5. Mereduksi data dengan membuat bentuk analisis yang menajamkan, menggolongkan, mengarahkan, membuang yang tidak perlu, dan mengorganisasi data dengan cara sedemikian rupa hingga mampu menarik kesimpulan-kesimpulan akhir dan diverifikasi.

6. Mengkomunikasikan kepada khalayak media massa, karena laporan berita yang belum dibaca atau tidak dipahami adalah laporan berita yang sia-sia.

Metode yang paling banyak digunakan dalam jurnalisme presisi adalah riset survei, atau lebih dikenal sebagai polling opini publik (meski pada beberapa penerapannya hanya mengikutsertakan sejumlah populasi khusus ketimbang publik secara umum). Menurut Meyer bahwa sebuah survei memiliki elemen-elemen sebagai berikut: ${ }^{8}$

a. Penetapan tujuan riset (An information goal or set of goals)

Tujuan riset ditetapkan terlebih dahulu agar para reporter atau jurnalis fokus pada isu laporan pemberitaannya. Sebuah data mentah yang didapat reporter harus diabstraksikan dalam struktur tertentu agar berguna dan dapat dipahami. Reporter harus meletakkan materi data ke dalam sebuah kerangka kerja yang akan membantu proses penginterpretasian dan

\footnotetext{
${ }^{7}$ Philip Meyer. The New Precision Journalism. (Bloomington, Indiana: Indiana University Press, 1991) hal. 7

${ }^{8}$ Philip Meyer. The New Precision Journalism. (Bloomington, Indiana: Indiana University Press, 1991) hal. 96-131
} 
pemahaman. Oleh karena itu, reporter memerlukan sebuah kerangka kerja persepsi, yang pada bidang-bidang juga disebut sebagai: skema, konstruksi, hipotesis, perkiraan, prinsipprinsip pengorganisasian, dan berbagai penyebutan lain.

Pada kajian yang lebih tinggi, skema, konstruksi, atau stereotip menjadi sebuah model teori. Model teori ilmiah mendeskripsikan bagian-bagian paling esensial dari suatu proses (baik natural maupun dengan campur-tangan manusia). Pendeskripsian dibuat sedemikian rupa sehingga memungkinkan dilakukan penarikan kesimpulan dari model tersebut, melalui pengujian dengan eksperimen maupun observasi. Keuntungan mengadopsi sebuah model teoritis bagi jurnalistik adalah, fokus reporter serta pembaca akan tetap terjaga pada isu permasalahan yang relevan. Hal ini mengingat banyaknya informasi peristiwaperistiwa yang kompleks yang terjadi dalam masyarakat. Sebuah model teoritis yang dapat dioperasionalkan akan dibutuhkan untuk memahami sebuah situasi. Meyer dalam salah satu risetnya sebuah logika dasar, yang menggiring pada hipotesis, melalui beberapa kalimat proposisi. Tiap proposisi harus bersifat sederhana dan dapat dioperasionalkan. Dengan merujuk pada pemaparan di atas, maka telihat bahwa para reporter, pada dasarnya sama dengan para peneliti. Mereka berurusan dalam hal pengujian realitas di lapangan, pengujian teori, mempertimbangkan sejumlah konsekuensi atas teori model yang dipilih, menyusun hipotesis terkait yang bisa dioperasionalkan, dan meletakkan mereka dalam pengujian.

b. Penetapan Sampel (A sample)

Prinsip penentuan sampel secara umum bergantung pada metode pengambilan data. Pengumpulan data sendiri dapat dilakukan melalui wawancara langsung, wawancara melalui telepon, atau melalui kuesioner. Terlepas dari metode yang dipilih, aturan statistik dasar dalam pengambilan sampel tetap berlaku yang mana setiap anggota populasi yang akan digeneralisasi harus memiliki kesempatan yang sama untuk diikutsertakan sebagai sampel.

Pengambilan sampel dari suatu populasi yang luas bertujuan untuk memastikan bahwa reporter telah melaksanakan pengambilan sampel sesuai prosedur, sehingga cukup kuat untuk melakukan generalisasi. Meski begitu, Meyer dalam bukunya menyarankan penggunaan metode probability sampling, yang menurutnya akan mudah diselaraskan dengan teori. Dalam desain risetnya reporter pun harus mempertimbangkan antara ukuran sampel dengan kelengkapan sampel.

c. Menyusun Kuesioner (A questionnaire) 
Tujuan dari langkah ini adalah untuk mengembangkan focal question, yakni suatu pertanyaan yang langsung menyentuh isu utama untuk dieksplorasi. Maka, pertama kali reporter harus membuat sebuah keterangan singkat sebagai pengantar sebelum membuat pertanyaan yang bersifat focal. Pertanyaan yang bersifat focal biasanya dibuat menggunakan jenis pertanyaan tertutup (close-ended question), sebuah cara untuk membangun jawaban ke dalam pertanyaan itu sendiri. Pertanyaan-pertanyaan tertutup selanjutnya akan lebih mudah dikoding dan ditabulasikan, karena jawaban-jawabannya telah dikonstruksi sebelumnya.

Pertanyaan-pertanyaan yang disusun reporter bukan hanya itu. Reporter juga harus menyusun pertanyaan-pertanyaan yang didesain sedemikian rupa agar mudah dipahami para responden. Reporter wajib menyusun pertanyaan senetral mungkin. Berbagai bentuk pertanyaan yang bersifat mengarahkan harus dihindari. Karenanya pada konteks tertentu, pertanyaan terbuka (open-ended questions) juga diperlukan, sehingga responen memilik kesempatan yang cukup untuk memberikan keterangan lebih.

Meski begitu, jika responden tidak akrab dengan tema atau isu utama yang diangkat, biasanya mereka tidak akan menjawab pertanyaan dengan tepat. Jawabanjawaban seperti ini yang selanjutnya akan sulit ditabulasikan. Kedua jenis pertanyaan tersebut memiliki kelebihan dan kekurangan masing-masing. Sehingga dalam penyusunan pertanyaan riset, kedua jenis pertanyaan tersebut harus ada. Reporter harus menstrukturkan kedua jenis pertanyaan tersebut, diawali dengan pertanyaan-pertanyaan umum. Selanjutnya dapat disodorkan pertanyaan-pertanyaan yang secara spesifik berorientasi kepada isu utama.

Setelah pertanyaan-pertanyaan selesai dibuat, reporter perlu melakukan pengujian. Sejumlah pertanyaan tersebut diberikan kepada beberapa pihak seperti para editor, pekerja editorial ataupun non editorial di koran dimana reporter bekerja, untuk diperiksa serta mendapatkan saran-saran perbaikan. Hal ini bisa mengurangi kemungkinan kekeliruan pengertian ataupun pertanyaan yang tidak jelas. ${ }^{9}$

d. Metode pengumpulan data (A collection method)

Setelah menyusun pertanyaan-pertanyaan, reporter harus menentukan metode pengumpulan data yang dinilai paling sesuai dengan tujuan riset. Pada dasarnya ada

${ }^{9}$ Septiawan Santana K. Jurnalisme Investigasi. (Jakarta: Yayasan Obor Indonesia, 2003) hal. 213 
beberapa metode yang bisa digunakan untuk mengumpulkan data seperti: wawancara langsung, wawancara melalui telepon, maupun dengan kuisioner melalui surat elektronik (email). Prinsip-prinsip dalam random sampling dapat digunakan untuk menentukan sampel dari setiap metode pengambilan data tersebut. Sampel dapat dipilih dengan cara pengundian, pengacakan sistematis dengan bilangan ordinal, atau juga dengan menggunakan tabel bilangan random.

e. Pengkodingan dan analisis data (Coding and analysis)

Data hasil survei dapat disajikan dalam bentuk tabel. Sebagai contoh, pada sebuah survei yang ingin mengetahui preferensi orang tua murid terhadap model belajar modular atau tradisional, sajian data dapat memperlihatkan persentase responden (frekuensi) yang memilih sistem modular, responden yang memilih sistem tradisional, responden yang tidak menjawab, serta demografi usia responden. Meyer menekankan, bahwa jumlah responden yang tidak menjawab atau menyatakan tidak tahu adalah juga merupakan data yang harus ikut diperhitungkan dalam rangkaian riset. Untuk menarik kesimpulan akhir biasanya digunakan teknik pengukuran dalam statistik deskriptif dan inferensial untuk menyajikan laporan berita yang terbaik bagi kepentingan publik.

Selain itu, jurnalisme presisi juga memerlukan aplikasi (software) seperti SPSS (Statistical Package for the Social Sciences), Geographic Information System (GIS) atau Sistem Informasi Geografis. ${ }^{10}$ GIS merupakan suatu alat yang dapat digunakan untuk mengelola (input, manajemen, dan output) data spasial atau data yang bereferensi geografis atau setiap data yang merujuk lokasi di permukaan bumi dapat disebut sebagai data spasial bereferensi geografis. Misalnya data kepadatan penduduk suatu daerah, data jaringan atau saluran dan sebagainya.

Financial data analysis atau analisis data keuangan yang menggunakan aplikasi atau software akuntasi salah satu aplikasi yang kadang-kadang diperlukan untuk jurnalisme presisi khususnya untuk pemberitaan mengenai pengungkapan skandal keuangan yang melibatkan tanggal-tanggal transaksi saham dan perdagangan bagi investor atau pemberitaan yang ingin meliput tentang korelasi besarnya sumbangan dana politik terhadap dukungan terhadap kandidat politik tertentu.

\footnotetext{
${ }^{10}$ Stephen K. Doig. "Precision Journalism". The International Encyclopedia of Communication,First Edition.Edited by Wolfgang Donsbach. 2012 (USA : John Wiley \& Sons,Ltd) hal. 3 DOI:10.1002/9781405186407.wbiecp096.pub2
} 
Jurnalisme presisi tidak hanya untuk proyek investigasi besar. Contoh topik yang lebih ringan bisa dilakukan dengan menggunakan metode tabulasi silang (cross tabulation). Misalnya pada laporan pemberitaan mengenai opini konsumen online shop pada Instagram atau laporan berita mengenai pendapat masyarakat tentang pilihan politik calon presiden dan calon wakil presiden 2019.

\section{PENERAPAN JURNALISME PRESISI DI MEDIA KOMPAS PADA PEMILIHAN KEPALA DAERAH (PILKADA) 2018.}

Praktik jurnalisme presisi bukanlah genre jurnalisme yang terlalu baru di Indonesia. Setidak-tidaknya sudah diawali harian Kompas pada April 1971. Saat itu Divisi Penelitian dan Pengembangan (Litbang) Kompas yang berada di bawah divisi redaksi, melakukan penelitian pendapat umum atau polling bertemakan pemilu. Hasil polling ini digunakan sepenuhnya untuk mendukung pemberitaan. Meski jurnalisme presisi juga pernah menghadapi tantangan pada Pemilihan Presiden (Pilpres) 2014 yang mana saat itu praktik jurnalisme presisi menjadi sangat populer. Soalnya, beberapa media penyiaran melakukan penghitungan cepat terhadap hasil Pilpres 2014. Namun ternyata hasil penghitungan cepat (quick count) itu ternyata berbeda antara yang disiarkan sebuah televisi swasta dengan televisi swasta yang lain. Tidak heran bila ada yang mengatakan bahwa penyiaran berita tentang hasil penghitungan cepat itu tidak lagi presisi. Sudah terjadi penggiringan opini masyarakat terhadap calon presiden dan calon wakil presiden tertentu.

Namun fenomena jurnalisme presisi dalam konteks Pilkada 2018 umumnya memberikan hasil yang akurat. Misalnya quick count yang digelar Litbang Kompas untuk kontestasi pemilihan gubernur dan wakil gubernur pada tiga daerah pemilihan di pulau Jawa yaitu Jawa Barat, Jawa Tengah dan Jawa Timur dengan mengambil sampel sebanyak 400 tempat pemungutan suara (TPS) tiap provinsi. Sampel dipilih dengan metode stratified systematic sampling yang tersebar di seluruh daerah dengan margin of error atau tingkat toleransi kesalahan tak mencapai 1 persen dan tingkat kepercayaan 99 persen. Mengutip Kompas online ${ }^{11}$ yang menjelaskan mekanisme perhitungan cepat yang persiapannya dimulai sejak Desember 2017 dengan kegiatan survei pra-pilkada. Tahapan pra-pilkada dilakukan oleh koordinator wilayah (Korwil) masing-masing provinsi. Korwil merupakan peneliti tetap dari Litbang Kompas.

\footnotetext{
${ }^{11}$ Sherly Puspita. Persiapan SDM Litbang Kompas demi Lahirkan Data "Quick Count" Akurat. Kompas. Com. 27 Juni 2018, dikutip melalui http://megapolitan.kompas.com/read/2018/06/27/10392981/persiapan-sdm-litbangkompas-demi-lahirkan-data-quick-count-akurat. (diakses pada 25 Juli 2018).
} 
Secara gamblang pihak litbang Kompas menyebutkan bahwa metode survei ini terbagi atas tiga tahapan. Tahapan pertama melakukan pemetaan (mapping) koordinator daerah (Korda) kota atau kabupaten. Lalu tahapan kedua melakukan pemetaan untuk koordinator lapangan (Korlap). Korda dan Korlap merupakan mahasiswa yang telah memiliki pengalaman bekerja sama dengan Kompas untuk melakukan survei. Langkah selanjutnya para Korlap akan merekrut mahasiswa-mahasiswa lainnya untuk menjadi interviewer atau pewawancara di lapangan. Mahasiswa yang direkrut menjadi pewawancara merupakan mahasiswa berbagai jurusan yang telah melalui proses seleksi oleh tim Litbang Kompas. Biasanya mahasiswa yang dipilih adalah mereka yang telah berpengalaman dalam proses penelitian khususnya mahir dalam metode survei. Sehingga setiap provinsi, akan ada 400 pewawancara, 97 orang koordinator lapangan, dan sembilan orang koordinator wilayah. Jadi, total ada 497 orang yang bekerja di lapangan di setiap provinsi. Selain itu hal yang paling penting sebelum hari $\mathrm{H}$ pemilihan maka tim lapangan melakukan tes atau cek lokasi untuk mengirim data TPS dan narahubung TPS termasuk data DPT (Daftar Pemilih Tetap). Mekanisme yang seru dalam perhitungan cepat menjadi tidak mengherankan jika Koordinator Pusat Kendali Litbang Kompas atau kerap disebut sebagai war room (ruang perang) antar kandidat kontestasi Pilkada.

Hasil perhitungan cepat Litbang Kompas untuk Pemilihan Gubernur dan Wakil Gubernur

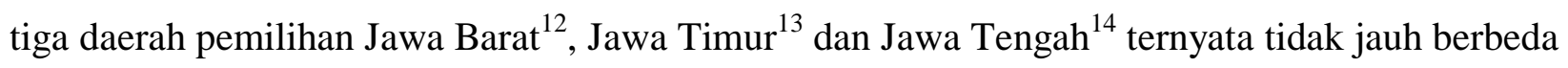
dengan perhitungan real count Komisi Pemilihan Umum Daerah (KPUD) ${ }^{15}$, berikut ini adalah daftar tabel hasil akhir pemenang perhitungan cepat versi Litbang Kompas dan perhitungan real count KPUD Jawa Barat, KPUD Jawa Timur dan KPUD Jawa Tengah.

\footnotetext{
${ }^{12}$ Mela Arnani, Akbar Bhayu Tamtomo. INFOGRAFIK Quick Count Litbang Kompas Pilkada Jabar Data 100 Persen: Ridwan Kamil-Uu Unggul, Kompas.com, 27 Juni 2018 dikutip melalui https://nasional.kompas.com/read/2018/06/27/18070031/infografik-quick-count-litbang-kompas-pilkada-jabardata-100-persen-ridwan yang diakses pada 27 Juli 2018

${ }^{13}$ Sherly Puspita. Quick Count Litbang Kompas Pilkada Jatim: Khofifah-Emil Menang. Kompas.com, 27 Juni 2018 dikutip melalui https://regional.kompas.com/read/2018/06/27/18023491/quick-count-litbang-kompas-pilkadajatim-khofifah-emil-menang. yang diakses pada 27 Juli 2018.

${ }^{14}$ Caroline Damanik. Ini Hasil Akhir 3 Quick Count Pilkada Jateng: Ganjar-Taj Yasin Menang. Kompas.com, 27 Juni 2018. Dikutip melalui https://regional.kompas.com/read/2018/06/27/22095401/ini-hasil-akhir-3-quick-countpilkada-jateng-ganjar-taj-yasin-menang yang diakses pada 27 Juli 2018.

${ }^{15}$ Lihat Daftar Hasil Penetapan Suara Pilkada 2018 dikutip melalui https://infopemilu.kpu.go.id/pilkada2018/hasil2/penetapan/list/nasional yang diakses pada 27 Juli 2018
} 
Tabel 1. Perbandingan hasil akhir pemenang Pemilihan Gubernur dan Wakil Gubernur versi Quick Count Litbang Kompas dan Real Count KPUD, 2018

\begin{tabular}{|l|l|l|l|l|}
\hline No & Daerah Pemilihan & Pasangan & Litbang Kompas & KPUD \\
\hline 1. & Jawa Barat & $\begin{array}{l}\text { Ridwan Kamil } \\
\text { Ruzhanul Ulum }\end{array}$ & $32,88 \%$ \\
\hline 2. Uu & Jawa Timur & $\begin{array}{l}\text { Khofifah Indar Parawansa }- \\
\text { Emil Dardak }\end{array}$ & $53,36 \%$ \\
\hline 3. & Jawa Tengah & Ganjar Pranowo - Taj Yasin & $58,34 \%$ & $58,78 \%$ \\
\hline \multicolumn{4}{|c|}{ Sumber : Litbang Kompas dan website KPU } \\
\hline
\end{tabular}

Perbandingan tabel di atas menunjukkan bahwa selisih data antara quick count versi Litbang Kompas dengan real count versi Komisi Pemilihan Umum Daerah (KPUD) setempat hanya sekitar 0,19 - 0,44 persen, perbedaannya begitu tipis dan tingkat akurasi begitu tinggi. Dengan demikian penerapan jurnalisme presisi di Litbang Kompas terbukti presisi dan mampu dijadikan barometer bagi masyarakat dalam kontestasi Pemilihan Umum Kepala Daerah di Indonesia. Secara historis atau sejak tahun 2007, Tim Penelitian dan Pengembangan (Litbang) Kompas telah memulai proyek hitung cepat (quick count) dalam pemilihan kepala daerah (Pilkada) berbagai provinsi di Indonesia dan pemilihan presiden (Pilpres). Di awali ketika Pilkada DKI pada 8 Agustus 2007 hingga terakhir Pilkada di Jawa Barat, Jawa Timur dan Jawa Tengah 27 Juni 2018.

Selain Litbang Kompas, Lembaga survei kredibel yang sering dijadikan acuan parameter media massa dalam melakukan quick count seperti Charta Politika, Lingkar Survei Indonesia (LSI) Denny JA, Saiful Mujani Research and Consulting (SMRC), Public Opinion \& Policy Research (Populi Center), Indikator Politik Indonesia, Poltracking Indonesia, dan Indo Barometer. Media massa sangat sering bekerjasama dengan lembaga-lembaga survei yang kredibel dan memiliki rekam jejak (track record) yang baik untuk dilibatkan pada setiap momen pemilihan umum. Data yang diberikan lembaga survei ini biasanya digunakan media massa sebagai data utama maupun sebagai data pembanding. Maraknya hasil survei yang dikelola oleh lembaga survei juga mengembangkan dinamika jurnalisme presisi di Indonesia.

\section{KESIMPULAN}

Jurnalisme presisi adalah kebutuhan mendesak bagi negara membangun yang menganut sistem demokrasi seperti Indonesia. Industri media massa di Indonesia menghadirkan jurnalisme presisi dengan alasan bahwa metode peliputan berita konvensional seringkali tidak lagi memenuhi keingintahuan khalayak untuk memahami dinamika fenomena sosial politik yang 
rumit seperti kontestasi Pilkada. Jurnalime presisi menjawab ekspetasi masyarakat agar menghadirkan kualitas berita yang kredibel, objektif dan komprehensif khususnya untuk isu pemilihan umum. Metode penelitian ilmiah yang sistematik, rasional, logis dan terukur adalah salah satu daya tarik jurnalisme presisi sehingga pada akhirnya peran jurnalis tidak hanya sekadar penyambung lidah rakyat tetapi juga sebagai saintis sosial yang tekun, jujur, teliti, objektif dan terbuka dalam mengkomunikasikan data kepada masyarakat.

\section{DAFTAR PUSTAKA}

Arnani, Mela dan Tamtomo, Akbar Bhayu. INFOGRAFIK Quick Count Litbang Kompas Pilkada Jabar Data 100 Persen: Ridwan Kamil-Uu Unggul, Kompas.com, 27 Juni 2018 dikutip melalui https://nasional.kompas.com/read/2018/06/27/18070031/infografik-quick-count-litbang-kompas-pilkadajabar-data-100-persen-ridwan.

Daftar Hasil Penetapan Suara Pilkada 2018 dikutip melalui https://infopemilu.kpu.go.id/pilkada2018/hasil2/penetapan/list/nasional.

Damanik. Caroline. Ini Hasil Akhir 3 Quick Count Pilkada Jateng: Ganjar-Taj Yasin Menang. Kompas.com, 27 Juni 2018. Dikutip melalui https://regional.kompas.com/read/2018/06/27/22095401/inihasil-akhir-3-quick-count-pilkada-jateng-ganjar-taj-yasin-menang.

Doig, Stephen K. "Precision Journalism". The International Encyclopedia of Communication, First Edition.Edited by Wolfgang Donsbach. 2012 (USA : John Wiley \& Sons,Ltd) . DOI:10.1002/9781405186407.wbiecp096.pub2

Eriyanto. Metodologi Polling: Memberdayakan Suara Rakyat. Bandung: PT. Remaja Rosdakarya, 1999.

Gehrke, Marília dan Meilniczuk, Luciana. "Philip Meyer, the outsider who created Precision Journalism". Intexto Volume 39, 2017. DOI: http://dx.doi.org/10.19132/1807-8583201739.

Meyer, Philip. The New Precision Journalism. Bloomington, Indiana: Indiana University Press, 1991.

Puspita, Sherly. Persiapan SDM Litbang Kompas demi Lahirkan Data "Quick Count" Akurat. Kompas. Com. 27 Juni 2018, melalui http://megapolitan.kompas.com/read/2018/06/27/10392981/persiapan-sdm-litbang-kompas-demilahirkan-data-quick-count-akurat.

Puspita, Sherly. Quick Count Litbang Kompas Pilkada Jatim: Khofifah-Emil Menang. Kompas.com, 27 Juni 2018 dikutip melalui https://regional.kompas.com/read/2018/06/27/18023491/quick-count-litbangkompas-pilkada-jatim-khofifah-emil-menang.

Santana K, Septiawan. Jurnalisme Investigasi. Jakarta: Yayasan Obor Indonesia, 2003. 